\title{
Performing Solidarity: Whiteness and Status-seeking in the Non-Aligned World
}

\author{
Jelena Subotic \\ Georgia State University, Department of Political Science, PO Box 4069, Atlanta, \\ Georgia 30302-4069, USA \\ E-mail: jsubotic@gsu.edu \\ Srdjan Vucetic \\ University of Ottawa, Graduate School of Public and International Affairs, 120 \\ University, FSS 6005D, Ottawa, ON K1N 6N5, Canada \\ E-mail: svucetic@uOttawa.ca
}

June 2017 draft (approx. 10,000 words). Earlier version presented at the 2016 Millennium conference "Racialised Realities in World Politics."

\begin{abstract}
The 1955 Afro-Asian Summit at Bandung is regarded as a pivot in the formation of Third World-ism and of coloured solidarity against Western colonialism and global white supremacy. But while this anti-imperialist spirit was no doubt present at Bandung, so were many other spirits, including those of Cold War realpolitik. We consider the different meanings of Bandung by examining the critical role Yugoslavia played in the rise of the Non-Aligned Movement in years that followed the summit. Drawing on primary historical documents, we show that Yugoslav leaders consistently failed to appreciate the racism of the international society and their own racialised privilege in it. They did appreciate, however, that performing solidarity with the decolonised and decolonising nations would bring major status rewards to Yugoslavia in the context of the East-West showdown. That self-consciously anti-imperialist and anti-colonial positions can be thickly enveloped in white ignorance suggests the need for more critical International Relations analyses of race, racism and racialised international hierarchies.
\end{abstract}

Keywords: whiteness, race, non-alignment, Yugoslavia, performance, status 


\section{Introduction}

Interviewed by Radio Belgrade on 27 April, 1955 about the meaning of Bandung, President Josip Broz, a.k.a. Marshall Tito, spoke with aplomb: “We, Yugoslavs, are particularly delighted with these results, for the conception which prevailed at the Conference is completely in harmony with our conceptions" (Tito 1963: 151-2). Five years later, at a session of the UN General Assembly in New York, Tito, together with India’s Prime Minister Jawaharlal Nehru, Indonesia’s President Sukarno, Egypt's President Gamal Abdel Nasser, and Ghana's President Kwame Nkrumah, announced the establishment of the Non-Aligned Movement (NAM). The entity appropriated virtually all of Bandung's political and symbolic capital: the conference's Ten Principles-a mix of United Nations (UN) principles of sovereign equality, human rights and justice and Buddhism-inspired notions of co-existence-as well as, crucially, the decolonising imperatives of the "Bandung Spirit." Then the Yugoslav leader then seized the opportunity to host the inaugural summit of the new movement. In September 1961, twenty five state delegations, most of them African and Asian, met in Belgrade to stake a credible claim in what today we would call global security governance. ${ }^{\text {ii }}$ The "Third World," a.k.a. the "Global South," expressed its identity anew, albeit on European soil.

In this article we use the Yugoslav role in the context of the NAM to demonstrate the operation of what philosopher Charles W. Mills calls "global white ignorance"-a social cognitive structure that undergirds white privilege and protection in the modern world (Mills 2015: 217, Mills 1997: 18). We show that self-consciously anti-imperialist Yugoslav leaders and diplomats, including the most seasoned critical Marxist intellectuals among them, consistently failed to apprehend the racist international society 
in which they lived. What they understood all too well, however, was that performances of solidarity with post-colonial Africa and Asia would bring status rewards for Yugoslavia—that is, positive recognition for Tito's regime and its alternative socialist modernity project. These performances transmitted but also distorted and blunted many decolonial norms. Anti-racism was one of them. By mostly affirming rather than confronting the existing international stratification based on race, Yugoslav foreign policy can thus be used to illustrate both causal and constitutive linkages between whiteness and ignorance on a global scale, as hypothesised by Mills (Mills 2015: 222).

We begin by discussing the Bandung-Brioni-Belgrade road, dispelling the main historiographic myths along the way. Next, we discuss how Yugoslav views and practices of "race" relate to Yugoslav policies towards the Afro-Asian world. Next, building on International Relations (IR) theories of status, we make an argument that these policies should be seen as status-seeking solidarity performances, followed by an empirical illustration. In a concluding section, we drew out the implication of our study for the critical and conceptual analyses of race, status and hierarchy more generally.

\section{Myths and Legends}

The intertwined histories of Bandung and the first NAM summit in Belgrade are generally poorly understood. Vitalis has shown that even professional historians fall prey to what he calls the "fables of Bandung" (Vitalis 2013). One of them is the notion that Tito personally led the Yugoslav delegation to the Indonesian city, where he planted the seeds of the NAM together with Sukarno, Nkrumah (also absent), Nehru and others. ${ }^{\text {iii }}$ Often, Bandung is erroneously classified as the birthplace of two broadly construed 
global identities. One is non-alignment - a form of Cold War neutrality. One is the identity of race-conscious "darker nations"- the ostensible pillar of the Bandung Spirit. iv In reality, as Vitalis points out, these identities were always "distinct and ultimately competing."v Also, with some exceptions, most delegates at Bandung avoided race-talk, some because they regarded it as undiplomatic, others because it smacked of the regressive belief in the biological division of humanity into races, and still others for fear of being labeled hypocrites (Vitalis 2013: 270). ${ }^{\mathrm{vi}}$

Recent historical re-assessments are in agreement with Vitalis in stressing pragmatism and opportunism as actor motivations (Kullaa 2012, Byrne 2015, Gerits 2016). Byrne, for example, finds that while "a non-Western, non-white identity" was articulated in some contexts, it was the more banal identity of non-alignment that dominated throughout. He also suggests that the effort to define the Third World racially_ “"to, in a sense, recast the cold war as a racial war" - had but one true state champion-the People Republic's of China (Byrne 2015: 214). From this perspective, not only was Belgrade no Bandung 2.0, but Bandung itself was not "Bandung." This is to say that the conference's political and normative imperatives were many and thus subject to "paradoxes, contradictions_-and some would say_-betrayals" (Pham and Shilliam 2016: 17). vii

Fables abound around the birth of the NAM, too. Much of the scholarship on Yugoslav foreign policy, for example, suggests that the Yugoslav "turn to the Third World" began shortly after the Stalin-Tito split—the 1948 expulsion of the Balkan country from the Cominform, Moscow-based coordinating body for the world's communist parties (Kullaa 2012: 16). Shunned and openly threatened by former Eastern 
bloc allies, Yugoslavia indeed declared itself independent and geopolitically nonengaged - a label for a peculiar mix of anti-Soviet rhetoric and a rapprochement of sorts with the West. Only in the middle or even late 1950s did Yugoslavia become nonaligned - meaning, an "independent anti-bloc power," to use a definition furnished by Moša Pijade, a key member of the Party's inner circle (Bondžić and Selinić 2008: 76). Another fable is that it was Tito himself who pivoted Yugoslav foreign policy towards the Third World. In reality, the policy originated in the Yugoslav Foreign Ministry led by Edvard Kardelj, another Party grandee and Foreign Minister from 1948 to 1953 . ${ }^{\text {viii }}$ Following the historian Svetozar Rajak, it can be said that key Yugoslav policy entrepreneurs were in fact two savvy diplomats stationed in New Delhi, Josip Đerđa and Josip Vilfan. Especially important were their policy memos to Kardelj on the benefits of courting, and learning from, the ant-blocist India (Rajak 2011).

Of course, the Indians did not much care about Yugoslavia at first. Yugoslav youth, union, party and parliamentary delegations that went to visit the newly independent Asian republic were all but ignored in New Delhi. The Indian disinterest began to shift only after a state visit in 1953 by Milovan Đilas, another Politburo and Party Secretariat heavyweight—Tito's putative successor, Đilas would later become a leading dissident—and Aleš Bebler, the country's deputy foreign minister and UN delegate. The two of them put Yugoslavia on Nehru's mental map, thus paving the way for Tito's own trip to New Delhi a year later. Were it not for the diplomatic finessing, Tito would have not had much access to Third World leaders like Nehru and Nasser. ${ }^{\text {ix }}$ Some historians like to point to the Tito-Nehru Joint Statement of 23 December, 1954 in New Delhi as the NAM's founding document of sorts. This is debatable. ${ }^{\mathrm{x}}$ What is 
certain is that the India trip emboldened Tito. Sailing through the Suez Canal in January 1955 on his way back to Yugoslavia, the Yugoslav leader made sure to talk nonalignment with Nasser. Then, on 2 April, the Executive Council of the Communist Party of Yugoslavia—one of the country's most powerful governing bodies—convened to talk about Bandung and post-Bandung activities, with top leaders all arguing for more engagement with like-minded African and Asian countries (Bondžić and Selinić 2008: 80). This resulted in the Brioni Declaration: on 18-19 July, 1956, Tito managed to bring both Nehru and Nasser to the Yugoslav island, where they together endorsed the "nonaligned cause." While it is again historically debatable whether Brioni set in motion the NAM's organisational wheels, it is certain that Nasser, Nehru and Tito would later happily proceed to patriate, both individually and jointly, the origins of the movement.

\section{Whence Yugoslav Whiteness?}

Historical documents indicate that Yugoslav leaders and diplomats avoided any talk of race in the run-up to the NAM. ${ }^{\mathrm{xi}}$ The Brioni Declaration mirrored some Bandung declarations, but the critique of colonialism was conspicuously absent, deemphasised in favor of anti-blocism and the prevention of nuclear disasters. Arguably, Tito's first major engagement with the problem of decolonisation was during his address to the UN General Assembly on 22 September, 1960 (Mišković 2014: 7). Yugoslav leadership speeches at the subsequent conference in Belgrade expanded on this further, including Tito's own, joined the chorus of those promoting racial equality and the distribution of wealth on a global scale (Parker 2011). On balance, however, simple anti-blocism was dominant throughout. In Rubinstein's words: “Tito’s formulation for nonalignment 
proved more viable and valuable than the all-encompassing racial-political format of the architects of Bandung” (Rubinstein 1970: 57).

Rubinstein's interpretation is Eurocentric in the sense that it elides the fact that Nasser and Nehru also tended to minimise the racial dimension of Bandung, albeit each for different, context-specific reasons (Vitalis 2013, Byrne 2015, Davis and Thakur 2016). That said, it is certainly the case that Tito had a unique "formulation for nonalignment." He and other Yugoslav communist leaders made frequent discursive connections between socialism and post-colonialism as natural allies, as extensions of one another. They did so along two main lines: Yugoslavia's shared colonial past and Yugoslav socialism being a natural ally of the post-colonial struggle. Along the first line of solidarity, in many political speeches, Yugoslav leaders compared African nations under European colonial rule and the nations of Yugoslavia under the colonial rule of the Habsburg monarchy and the Ottoman empire as a way to position Yugoslavia as having a post-colonial experience, thus setting up a direct point of solidarity with other noncommitted countries (Sladojević 2015). Communist theorists of the time, for example, compared the circumstances under which India, Yugoslavia, and Egypt chose nonalignment, arguing for the similarities in the three countries' shared experience with foreign domination, with being part of the developing world, with defending their independence from great powers, and with shared opposition to the existing international order after World War II (Tadić 1976, Spaskovska 2015).

A related point of affinity was the similarity of Yugoslavia and the developing African and Asian nations' status in international affairs, such as isolation and economic “backwardness" (Bogetić 1990). But Yugoslavia's positioning itself as being in solidarity 
with the post-colonial experience placed it as "discursively equal but privileged",

(Sladojević 2015: 12) as a helpful older sibling who "replaced the leopard hide for the worker's overalls" (Sretenović 2004: 6, quoted in Sladojević 2015: 12). It is this construction of "international help," more than of "international solidarity" that helps explain Yugoslav interest in the Third World. Here is a message from Tito himself:

We have also realised that we must help [distant Asian and African countries] as much as possible, that there are means to do so... They perceive us as an example and aim to create more, even though they started off from much more devastating circumstances than we have and that is why it is necessary to help them. Let the friendship that we are building with those people be long-lasting, for our yearnings are the same; long-live the cooperation between peoples! (Tito 1959).

The second line of solidarity was based on the character of the Yugoslav communist revolution, which was seen by many of its leaders as similar in kind to the anti-colonial struggle. For example, Leo Mates, a leading foreign policy expert of the time wrote that even though the communist revolution was not principally anti-colonial in nature, its character was not only socialist but also liberating and independence seeking, which makes it similar to the liberation movements in the colonies (Mates 1970: 194). Others have made the argument that Yugoslavia's non-aligned orientation is simply the extension of its state identity, and is a natural foreign policy shield that will help the country realise the goals of its socialist revolution (Bogetić 1990: 10). Tito himself argued that "self-management within the country and non-alignment in international relations represent the totality of the policy of independent Yugoslavia (Tito and Kardelj 1977: 44). A Titoist brand of official multiculturalism and multiethnicity called "brotherhood and unity" was part of this equation, too (Drapac 2010).

Was a more emancipatory policy even possible for the Yugoslavs in those years? We think the answer is no. In search for the official and officious discourse on race in this 
period we examined hundreds of primary sources, public speeches, committee meetings' minutes, foreign travel reports housed in Yugoslav archives, plus major theoretical and political texts on "Yugoslavia in the world" and popular travelogues produced and/or likely to be consumed by the ruling elite. ${ }^{\text {xii }}$ Our main finding is that "race," simply, was not an important analytical or political category in Yugoslav communist thought and practice. The world these documents described was one of socialists and non-socialists, oppressed and oppressors, weak and strong, but it was not a racialised world. ${ }^{\text {xiii }}$ For example, in an interview with Hindustan Standard in 1953, Tito was asked, "Could a great problem of racial discrimination of minorities, which is an impediment to peace, be solved with cultural and ethnic fusion?" His answer did not address race at all, and instead he responded, "In regard to the colonial question we have a very clear position we support the right of every nation to self-determination" (Tito 1977: 32). He expressed similar views years later in Africa (Hozić 2016).

In their attempt to differentiate Yugoslavia's experience from that of the global South but also express post-colonial solidarity, Yugoslav officials quite consciously retained its position as a European polity in its dealing with the Third World, expressing itself as white and European but never a coloniser itself (Sladojević 2015: 17). This, as Rajak contends, was one of the sources of Tito's great success among Asian and African leaders: "he was the first white European who did not come to subjugate and arrived instead as an equal, professing independence and mutual respect" (Rajak 2014: 179). The main point, however, is that he positioned himself as a travelling white European, not as a socialist revolutionary bent on smashing global white supremacy (Kilibarda 2010, Hozić 2016). 
To be sure, the fact that Yugoslavia's communist leadership understood the racial issue as a colonial issue is prima facie is unsurprising. Yugoslavia's lived experience with the forces of oppression and coercive domination was different than that of Third World countries. ${ }^{\text {xiv }}$ That said, our evidence shows that mid-twentieth century Yugoslavs, ruling elites and masses alike, had a distinct superiority complex vis-à-vis their African and Asian friends and allies. Diplomatic dispatches and travelogues various foreign policy officials and foreign correspondents sent back home are particularly illuminating on this point. In one 1961 collection of foreign dispatches, the editor of the volume writes that "travelogues orient us politically... they describe the most distant places and regions still unliberated from colonial policies and discrimination" (Hadžić 1961: 6). The dominant tone in these travelogues is not one of racism directly but more of cultural superiority. Various foreign peoples are often described as "small undeveloped nations," while Yugoslav visitors come from a "developed socialist country” (Hadžić 1961). More overt disdain is reserved for foreign religious practices as in a report from a visit to Iran, where the writer describes "disgusting and exotic dervishes, begging apostles of Persian mysticism", a "fanaticism" of the "severe grins of the mullahs" (Radenković 1961: 291). Indeed, little separates this writing from the travelogues published in the interwar period (Milutinovic 2008, Šmitek et al 1993).

The country's cultural diplomatic practices are equally illuminating. In 1951 Yugoslavia began a large program of granting scholarships to foreign students from countries soon to be refereed to as "nonaligned" to study at Yugoslav universities. This program was seen as an extension of Yugoslavia's multilateral cooperation with its new international friends and, explicitly, designed for students from those countries to which 
granting of scholarships "would be beneficial within the framework of [Yugoslavia's] general political direction" (Savez socijalističke omladine Jugoslavije 1958. See also Bondžić 2011), with the clear shift to students from the non-aligned countries occurring in 1959.

The program started with the modest four students in 1951 and reached a high of 1,067 in 1961 (Lazić 2009: 63). Many of the foreign students - who mostly hailed from Africa and Asia - complained about their treatment. They were often socially ignored, had a hard time making friends with the Yugoslav locals, but were also subject to more overt discrimination as in being denied apartment rentals or charged much more than the locals. The level of discrimination was so high that it alarmed the political leadership of the program who admitted in an internal report, "our students, even the communists, are avoiding to socialise with the foreigners" (cited in Lazić 2009: 70). ${ }^{\mathrm{xv}}$ There were also reports of physical abuse of foreign students by not only their Yugoslav colleagues but also the police that was supposed to protect them - such as a spike in these incidents directed at students from Togo and Algeria that occurred around New Year's Eve in 1961. Students from African countries often complained of being subject to racial slurs, and the word "monkey" for African students became common practice (Lazić 2009: 73; Bondžić 2011: 272, 284-86). ${ }^{\mathrm{xvi}}$

Absent this broader socio-cultural context, Yugoslav relationship to the NAM cannot be fully understood. While racist ideology was rejected by Yugoslav communism, which prided itself on political and even cross-cultural solidarity with oppressed nations, giving birth to non-alignment, the lived experience of non-alignment in Yugoslavia was much different. The Yugoslav leadership showcased Yugoslavia's many commonalities 
with the newly independent nations of Africa and Asia, while at the same time failing to meaningfully support their individual and collective efforts at anti-racist politics, much less transform local behaviors and entrenched racist attitudes towards non-alignment others. In fact, such attitudes—if not overly racist, then deeply Eurocentric—can be found in the text left by Party dignitaries, as when Koča Popović (Chief of Staff) and Veljko Mićunović (Deputy Foreign Minister), both of them well-travelled Marxist intellectuals, went on record to oppose Yugoslavia's allying itself with "the world of miserables" (Rajak 2014: 157). ${ }^{\text {xii }}$

Evidence of these deeply entrenched feelings of Yugoslav socialist "superiority" over the non-aligned others is also found in the diplomatic backgrounders prepared by the Yugoslav party officials and foreign office in preparation for Tito's major trips abroad during this period. For example, in preparation for his trip to Asia in 1954, Tito received a briefing "General Comments on Asian Socialism," which contained these observations: "Asian socialism (...) is slow, rigid, insufficiently dynamic. The strength of Asian socialism is not in its organisation, its ideological influence, in conscious socialist action, but in the general development of the world, which is moving toward socialism... Escape toward Gandhism, Buddhism, is not so much a sign of conviction, as a sign of the subjective factor, in fact ignorance of Marxism, or its very superficial knowledge" (Archive of Yugoslavia, Office of the President, KPR I-2/4).

This background material also offers a rare glimpse into Yugoslav communist understanding of race. In the backgrounder prepared for Tito's trip to India in 1954, among a variety of economic, cultural and political background information, is a section on "Racial, Religious, and Social Structure of Society." This document begins by 
dividing the Indian population into six major groups: "Negrito, proto-Australoids, Mongoloids, Mediterraneans, Western Brachiocephaloids and Nordics.” The document then goes on to further specify Indians according to their "racial-physical characteristics" into "Turkish-Iranian, Indo-Aryan, Skheet-Dravidian, Aryan-Dravidian/Hindustan, Mongolian-Dravidian, Mongolian, and Dravidian” (Foreign Office of Yugoslavia 1954). The backgrounder prepared for Tito's visit to Burma in November 1954 includes the same kind of racial demographic information, which for example includes observations on particular "loyalty and work ethic of the ethnic Chinese", as opposed to the rest of the Burmese diverse population, and notes as problematic the "warlike Urdu tribes" (Foreign Office of Yugoslavia 1954).

Often, reports from overseas visits included not only detailed observations about the Asian countries' "underdevelopment," but also projections of Yugoslavia's own international reputation and status, as viewed by these Asian others. For example, in a speech president Tito gave in February 1955 upon his return from India and Burma, he reports, “... we were taken such good care of and told on every occasion that we were not representatives of a small country, but instead representatives of a great people and a great country judging by our moral qualities, our struggle and what our nations have already achieved" (Tito 1955).

We think this context matters for explaining the rise of the NAM. At a minimum, it suggests that Yugoslav contribution to decolonial struggles was ambiguous. On the one hand, never before did a European country align itself with the postcolonial South. On the other hand, however, this alignment was inherently limited. For one, Yugoslavia's brand of developmentalism was indirectly to the West's political benefit. As reported in a 
British Foreign Office dispatch from 1959: "Ideas of this kind are much more likely to make an impression on the Asian mind if they are put forward by the Yugoslavs than if they come from Westerners whose views tend to be discounted as propaganda. We think that the Yugoslavs have done some useful work in this field" (Rajak 2016: 79). This is an apt observation. The non-aligned internationalism of Tito's Yugoslavia was by no means a project to end global cultural suppression. Rather, as we show next, it involved a situation where positive images of the Third World struggle were crafted and curated by policy-makers and disseminated for specifically Yugoslav intents and purposes.

\section{Nonalignment as Status, Solidarity as Performance}

IR is experiencing a renewed interest in international hierarchy (for a review, see Mattern and Zarakol 2016), and therefore in status (De Carvalho and Neumann 2014: 18, fn. 7; Duque 2016: 2-4). Traditionally, IR research has regarded status as something states possess as opposed to that which is established though social relations (for discussions, see Lebow 2008: Chs 1-2; Pouliot 2016: Ch 1). But even though virtually all contemporary definitions emphasise the latter ontology, much theorising and analysis proceeds by reducing status to overt material manifestations. For example, Volgy, Miller et al. 2014) investigate several possible measures of status that can be used in regressionbased analyses, including surveys of diplomatic historians, diplomatic missions received, state visits received by states with above-average capabilities, and elected office holding in the UN. They ultimately settle on what they identify as the "default option": "the volume of diplomatic contacts sent by states to other" (Ibid.: 14). The rationale is the notion of "status attribution": given that states are constrained by resources, diplomatic 
contacts - those taking place in state capitals, at the ambassadorial level or higher-can be said to "reflect" state perceptions and social comparisons (Ibid.: 15-16).

Scholars working in the tradition of social network analysis are better at aligning ontology and theory. In a move that emphasses social relations, (Maoz 2011) analyzes the relative status of states by measuring network centrality across different dimensions of international participation. Duque (2016), in the most sophisticated study yet, analyzes tie formation in the network of embassies as a way of capturing status defined as recognition. In this approach, the international status hierarchy becomes inseparable from social practices and self-reinforcing rather than a set of indelible attributes.

Eschewing the desire for empirical generalisations, interpretatively oriented scholars are far more faithful to the intersubjective ontology underpinning the concept of status hierarchy. A collection edited by De Carvalho examines the multifaceted ways that Norway has played, and continues to play, status games in and through the pursuit of "good citizenship" in the international society (De Carvalho and Neumann 2014). Here, status is a dimension of (intersubjective) state identity relations and of international hierarchy formation, while status-seeking is the (subjective) search for recognition (De Carvalho and Neumann 2014: 5, 7). De Carvalho and Neumann also add that peer groups are both objective (e.g., regional membership) and subjective ("like-minded countries"), and these categories can and do overlap. Norway's main peer groups are thus the Nordics (Sweden, Denmark, Finland) as well as that nebulous group of states that, like Norway, are "fairly small, fairly wealthy, democratic and all eager to spread their moral capital" (Canada, the Netherlands, Sweden etc.) (De Carvalho and Neumann 2014: 13). ${ }^{\text {xviii }}$ So viewed, Norway's "active" support for the successive iterations of the post-1945 Pax 
Americana has been a remarkably successful status-seeking strategy, certainly when contrasted with the "low status" life of states who are either "passive" (the authors' example is Belize) or, worse, behaving badly (Sudan) (De Carvalho and Neumann 2014: $10)$.

De Carvalho and Neumann's broader view of status helps interpret the Yugoslav position, but only to an extent. A socialist country that ended up falling in the geopolitical gap between the Soviet-led socialist bloc and the United States-led capitalist West certainly sought to be recognised as such: an independent small state claiming some sort of neutrality. Helping create the NAM can thus be seen as a status-seeking move that helped Yugoslavia and Tito's government survive at home and abroad. ${ }^{\text {ix }}$ However, several puzzles remain. First, Yugoslavia sought status by opposing or subverting the international order - that is, behaving more like Sudan than Norway in the above sense. ${ }^{\mathrm{xx}}$ The Third World movement that passed through Bandung and Belgrade was in various proportions anti-Cold War and anti-global North - a joint effort geared at "changing international relations together" (Bogetić 1990: 209; also see Mišković 2014: 13) or “creating a new world order” (Bilandžić 1985: 219).

Second, Yugoslavia actively sought a leading role in the new movement. Claims of primacy are an aspect of status-seeking, but the newly independent Afro-Asian nations cannot be interpreted as Yugoslavia's peer group on either objective or subjective criteria (De Carvalho and Neumann 2014: 15). Finally, this policy was largely if not spectacularly successful. In the six years from Brioni to the Belgrade summit, Yugoslavia managed to legitimately claim leadership of a movement representing "half of the world's 
population"- - an unlikely feat, considering Yugoslavia's size, wealth, geographic location and history (Drapac 2010, Spaskovska 2015).

We address these puzzles by mobilising performance theory—a convenient shorthand we use to refer to a set of interlocked studies in sociology, anthropology, history and IR (Alexander 2006, Ringmar 2012, 2016; Dinkel 2014, Shimazu 2014). We treat these studies as a single body of work because they are often as much in dialogue with each other as they are with their respective disciplines. For example, Ringmar's IR analysis of how international systems are framed, scripted, and performed builds on Alexander's work in sociology, while Shimazu's analyses of the staging of the Bandung conference builds on the studies by both Alexander and Ringmar. Furthermore, Shimazu and Ringmar are both interested in insights from theatre studies as well; indeed, as the latter puts it, theatrical metaphors have since the early modern era been at the center of European imaginations of the system —a "world stage"—of sovereign state "actors" (see, especially, Ringmar 2016: 113-8). Explicitly or otherwise, all these studies build on the much earlier contributions by Johan Huizinga, Erving Goffman, Clifford Geertz, Victor Turner, Bourdieu and others - contributions that we cannot discuss for the sake of space. ${ }^{\mathrm{xxi}}$ The same goes for the work of historians of Titoist Yugoslavia who also occasionally turn to performance theory to explain "everyday life" (Vuletic 2010, for example).

Our explanatory framework follows Ringmar in defining performances as events that bring discourses and audiences together: they are the prosthetics that actors use to "frame" situations and enact "scripts." Political speeches, for example, are performance with the potential to constitute the objects they invoke-depending on how they 
harmonize or resonate with practices that make international political life possible. From this perspectives, individual and institutional representatives of states are essentially actors who routinely stage performances. ${ }^{\text {xii }}$ What determines the success of a performance is an audience response: the actors' performance can be recognised as legitimate or not. In Shimazu's analysis, for example, the city of Bandung was the stage, Sukarno the leading performer, his fellow Indonesians the primary auditorium, and Indonesia's revolution its main script. This performance was successful in the sense that it conferred legitimacy on Sukarno and his regime, and thus greatly empowered him in Indonesia's inaugural general elections later that year, as well as in various ideological and territorial struggles in which the Indonesian Republic was then involved (Shimazu 2014: 251-2; also see Vitalis 2013: 271).

Theoretically speaking, the success of performances depends on practices and phenomena that are not reducible to the actions, beliefs or desires of any single member of a given society. A basic social-theoretic teaching is that there are many relations, processes and mechanisms by which social structures mesh with individual action and interaction, which is why scholars sometimes invoke concepts such as "discursive fit" "embodied meanings and others to understand how people come to evaluate specific performances" (Ringmar 2016, 111-3). Whatever the underlying configurations, the quality of performances has direct status ramifications. Indeed, to the extent that statusseeking cannot be divorced from the search for recognition, the relationship is rather straightforward: the more successful the performance, the better the chances for higher status. This is why states choose which type of diplomatic performance to engage in 
depending on what they imagine themselves to be and what they imagine their role in the international society is.

To illustrate how this framework explains the success of Yugoslavia's Third World internationalism, let us begin by categorising Yugoslav NAM-oriented performances into summit spectacles, diplomatic and cultural networking, and Tito's personal diplomacy. The Tito-Nehru-Nasser summit in 1956 in Brioni is arguably Yugoslavia's first solidarity performance with the Third World. Considering its impromptu nature, it was a spectacular success. The Brioni Declaration, issued through a joint press conference targeting audiences at home and abroad, allowed Tito to claim parity with the heads of much larger and potentially far more morally authoritative countries. Subsequent events- the Suez Crisis, the Hungarian Revolution, the growing confluence of Yugoslav and Egyptian foreign policies in the 1958-1960 period (Kullaa 2012: 3) — together helped turn that moral claim into the NAM, the crown jewel of Yugoslavia's soft power. The clincher was the meeting of the leaders of non-aligned countries in Belgrade, the Yugoslav capital, from 1 to 6 September, 1961. There, much like in Bandung, the cityscape was reorganised to act as both the stage and performer. No expenses were spared. "[F]orty new streets were constructed, infrastructure was updated, the first neon signs appeared in the city center" (Hozić 2016, 91). Two new green areas sprung up, one named "The Park of Friendship", the other "Avenue of Peace", where visiting leaders "planted new trees 'to give visible expression' to their newly found solidarity" (Hozić 2016). All of this came in addition to the displays of national flags at the airport and elsewhere, motorcades, fireworks and other mid-twentieth century 
pageantry of state sovereignty. There was even a state dinner for 2,000 people, with Tito and Jovanka as hosts. ${ }^{\text {xxiii }}$

These efforts meant that Belgrade became a global media spectacle for a week; a “paradise for cameramen" and a "photographers' and cartoonists' dream”, as the correspondent for The New York Times put it at the time (cited in Dinkel 2014: 209). ${ }^{\text {xxiv }}$ As Dinkel explains, while all post-1945 anti-colonial and non-aligned summits were performances aimed at an assumed 'world opinion', it was Belgrade that set the new media standard by providing new press centers and accommodation of hundreds of journalists, establishing new communication frequencies, new radio and TV stations and even the interlocking information bulletins in which Yugoslavia became 'regular news' in India and vice versa, thus creating solidarity and identity where none had previously existed. ${ }^{\mathrm{xxv}}$ When U Nu of Burma declared in his conference speech, "the whole world has its eyes on Belgrade today," he was certainly right about the Third World (Dinkel 2014). Pace Shimazu, the Yugoslav capital was not simply a stage where solidarity was performed but also a site for the re-articulation of meanings and therefore of claims to authority within the club known as the Third World.

The rapid expansion of the country's diplomatic network in Africa and Asia were another type of performance. No sooner than a newly independent ex-colony would declare independence and be admitted to the UN, the Yugoslavs would run to establish not only diplomatic contacts, but also various political, social, cultural, economic and military exchanges. For example, Yugoslav state press offices and Yugoslav socialist youth and student delegations ensured that their English language publications, photographs, films, learning modules, and other propaganda materials would go to places 
like India and Indonesia in equal if not larger numbers than to the regional and fellow socialist peers like Czechoslovakia. Same for the hosting of leaders, diplomats, and other foreign VIPs (Bondžić and Selinić 2008: 81; Rubinstein 1970: 185-6). Some of these exchanges were absurd, as when in 1964 the Yugoslav government transferred one of its newly acquired aircraft to the air force of a non-aligned friend-with no plan to help with spares or maintenance whatsoever (Janić and Simišić 2007: 67). And not all exchanges were gift exchanges, of course, as Tito regularly explained to Yugoslav audiences (Tito 1977: 19; Tito 1982). Indeed, Yugoslav diplomats in the NAM worked always hard to sell navy vessels to Ceylon, merchant vessels to Sudan, capital engineering projects to Ethiopia and, of course, weapons to Indonesia and Egypt (Rajak 2016: 75; Rubinstein 1970: 222).

Tito's personal diplomacy in Africa and Asia was a category of solidarity performance on its own. Following the same script, Tito would begin each "friendship visit" with his interpretation of the main global issues of the day. This would be followed by a history lesson on Yugoslavia's WWII liberation war, and then by a lecture on the success of the Yugoslav economic model (Rajak 2016: 74-5). As Hozić demonstrates, the fact that many of these trips, such as the long 1961 tour of Africa, were carried out on his luxurious presidential yacht Galeb (The Seagull), made the trips appear that much more glamorous: "his arrivals and departures always carefully choreographed and visually documented, with port cities and cheering crowds the perfect backdrop" (Hozić 2016: 7). For these "visual feasts," Tito made sure photographers were always on hand to document his every step (Hozić 2016). 
Each of these performances was to some extent racialised. Socialised into a Eurocentric conceptual apparatus and white ignorance, Yugoslav leaders and diplomats consistently positioned themselves as superior, or at least equal, to their Third World interlocutors. Certainly, Marxist-inspired ideas about solidarity and equality that Tito, Kardelj, Pijade, Đilas and other Yugoslav officials articulated in those years were often genuine. Yet, these ideas did not negate prejudicial views based on broader cultural coda, most of them actively reinforced within an international system that readily recognised white countries like Yugoslavia while repeatedly denying non-white equality (Mills 2015: 222; also see Kilibarda 2010). Absent this structure, Yugoslav leadership would arguably hesitate in attempting to join the NAM, to say nothing of claiming a leadership role within it. ${ }^{\text {xxi }}$

By any reasonable measure, these performances brought Tito's Yugoslavia major status rewards. By September 1960, when Tito met with Nasser, Nehru, Nkrumah and Sukarno at the Fifteenth UN General Assembly in New York to discuss the increase in Cold War tensions and the need for what became the NAM, Yugoslavia was a diplomatic powerhouse in the Third World. Kennedy and Khrushchev both welcomed the Belgrade summit in public, even if privately they expressed all sorts of discomfort with it. The U.S. foreign apparatus, spinning over the 1961 Berlin crisis, was deeply split between the hostile Department of State—George Kennan was the U.S. Ambassador in Belgrade from March 1961 to July 1963—and the more liberal White House staffers like Adlai Stevenson, who argued that it is in the U.S. interest to show support for nonaligned internationalism (Rakove 2014). The Soviets reacted similarly, concluding in private that they could best manipulate the NAM by publically supporting most of its 
pronouncements (Kullaa 2012). Crucially, both superpowers recognised Tito's Yugoslavia "disproportional" influence and role (Irwin 2016: 147; cf. Rubinstein 1970: 319). Similar recognition also came from London, Paris and Beijing, as well as from international organisations (Rubinstein 1970: 119; Čavoški 2014, Rakove 2014, Lees 1997). In his 1970 book, Rubinstein wrote:

A number of nonaligned diplomats noted that Washington and Moscow, for example, tend to see Tito as more important than he really is because of Yugoslavia's important role among the nonaligned countries: "Great Powers tend to evaluate Tito in the light of how Africa sees him, and vice versa" (Rubinstein 1970, 186-7).

Certainly, the ability of Yugoslav leaders and diplomats to establish themselves as a "hub" between and across Cold War blocs and anti-bloc forces is one secret behind Yugoslavia's relatively high status in those years. For example, the aforementioned student mobility programs targeting African and Asian students certainly helped make Yugoslavia's bid for membership in the Third World more credible. Yet, Yugoslav success was more fundamentally a function of performances, including the repetitive and consistent enactment of the script of the "common cause" covering everything from alternative socialist modernities to military-industrial developmentalism to the double opposition to the rigid bloc structure of the Cold War and the colonial rapaciousness of the global North. ${ }^{\text {xxvii }}$ Like everyday practices—activities that take place in front of other members of society who process what they see either consciously or unconsciouslysuch performances take place in front of designated international auditoria regularly. But while all status theories in IR emphasise the importance of diplomatic communication and interaction in the broadest sense, little is said about their performative dimensions. 
Without apprehending the latter, however, it is difficult to see how Yugoslav leaders and diplomats could achieve what they did.

Of course, one needs not dismiss solidarity performances as "completely" inauthentic and hypocritical or "merely" pragmatic and opportunistic. Whatever their rationality, such efforts matter because they can and do shape collective expectations about what types of behaviour are acceptable within the international society, thus enhancing a sense of responsibility among member polities vis-à-vis one another and with respect to global governance functions. Also, in this perspective reality exists through performance, not before it. As such, performances are potentially transformative in the sense that they help the public imagine new realities-and sometimes radically new realities. In this way solidarity performances may well open the door, if ever so slightly, for creating a more just world.

\section{Conclusion}

We have argued that twentieth century Yugoslav participation in the Third World movement in general and the NAM in particular was a status-seeking performance-a series of explicitly staged claims of moral authority and leadership. Texts left behind by insiders and outsiders alike indeed reveal an abiding concern with status and an understanding that nonalignment and the NAM offered Yugoslavia an opportunity to position itself as a progressive and leading power. The strategy proved successful. The Yugoslav state and its leaders achieved a relatively high international status quickly and cheaply in the 1950s and 1960s, more or less maintaining it until the country's collapse in the 1990s. Contrary to the literature on small states and status, this feat was achieved by 
opposing the international order-not only the nuclear-armed blocism of the Cold War, but also the political, economic and cultural subordination of the South by the North.

Central to the Yugoslav success were performances of political solidarity. While Yugoslavia never claimed to be in the same post-colonial trajectory as Afro-Asian nations, its leaders and diplomats regularly positioned themselves and the country they were representing as an honorary member of the Third World. The theatre, in this case, could be seen as more than a metaphor: if Yugoslav anti-Cold War, anti-imperialist posturing had elements of social theatre, akin to Brechtian théâtre engage, then Yugoslav contributions to global anti-racist struggles were little more than improvisation, as in commedia dell'arte.

Yugoslav interpretations and solutions of oppression and coercive domination associated with colonialism were at best Marxist, rarely if ever decolonial. The record of mid-twentieth century Yugoslav development assistance practices, as well as Yugoslav daily life, confirm this reading, suggesting that the Yugoslav state had little real potential for engagement with issues of racial supremacy and racially-coded colonial and postcolonial practices that emerged in the run-up to the NAM. Although it sided with countries like India, Egypt and Ghana in challenging the world order politically and economically, the Yugoslav state, leaders, and citizens nevertheless culturally participated in, and contributed to, the ideologies and practices of global white supremacy. Influence vis-à-vis the First and Second Worlds thus went hand in hand with a sense of superiority over the Third.

Our analysis has two important implications for the critical and conceptual analyses of race and hierarchy in IR. First, a self-consciously anti-imperialist and 
otherwise progressive position, that does not explicitly address the structures of white supremacy, will reproduce familiar patterns of global white ignorance. Second, to the extent that modern international and transnational efforts to achieve human equality and global justice are to various degrees performative, then there may be good reasons to conclude that racialised status hierarchies are more entrenched than intimated in the scholarly literature. 


\section{Acknowledgements}

We would like to thank Catherine Baker, Dragan Bogetić, Dragomir Bondžić, Elizabeth Dauphinee, Marina Duque, Aida Hozić, Nemanja Radonjić, Slobodan Selinić, Ana Sladojević, Ljubica Spaskovska, Irina Subotić, the staff at the National Library of Serbia, the Archives of Yugoslavia, the Museum of Yugoslav History, the Museum of African Art in Belgrade, participants of the 2016 Millennium conference "Racialised Realities in World Politics," editors of the Journal of International Relations and Development, and two anonymous reviewers for very helpful comments and suggestions.

\footnotetext{
About the authors

Jelena Subotic is Associate Professor of Political Science at Georgia State University. She is the author of Hijacked Justice: Dealing with the Past in the Balkans (Cornell University Press, 2009), as well as numerous articles on transitional justice, identity politics, and the Balkans. Her recent research has focused on historical memory and narrative.

Srdjan Vucetic is Associate Professor at the Graduate School of Public and International Affairs at the University of Ottawa. His research interests revolve around identity politics and international security. He is the author of The Anglosphere: A Genealogy of Racialized Identity in International Relations (Stanford University Press, 2011).
} 


\section{APPENDIX}

\section{Archives}

Arhiv Jugoslavije: Kabinet predsednika Republike

Diplomatski arhiv Ministarstva spoljnih poslova Republike Srbije: Politička arhiva

\section{Newspapers}

Borba (Belgrade)

Politika (Belgrade)

\section{Travelogues, Speeches, Biographies, Memoirs \& Interviews}

Davičo, Oskar (1962) Crno na belo (Beograd: Prosveta) Retrieved on 11 September, 2016 from

https://kok.memoryoftheworld.org/Oskar\%20Davico/Crno\%20na\%20belo\%20(59)/Crno \%20na\%20belo\%20-\%20Oskar\%20Davico.pdf

Dedijer, Vladimir (1970) Memoirs of Yugoslavia, 1948-1953 (New York: Viking). Dedijer, Vladimir (1980-1984) Novi Prilozi za Biografiju Josipa Broza Tita. 3 Vols (Zagreb: Mladost).

Mandić, Blažo (2012) S Titom: Četvrt veka u Kabinetu (Beograd: Dan Graf) Nenadović, Aleksandar (1989) Razgovori s Kočom (Zagreb: Globus) Petrović, Slavoljub Đera (2012) Sećanja i zapisi borca i diplomate (Beograd: DTA) Petrović, R (1930) Afrika. (Beograd: Geca Kon) Retrieved on 11 September, 2016 from https://www.rastko.rs/knjizevnost/umetnicka/rpetrovic/putopisi/rpetrovic-afrika.html 
Popović, Koča (1949) Revision du Marxisme-Leninisme au sujet de la guerre de liberation en Yougoslavie (Paris: Livre yougoslave).

Štambuk, Zdenko (1957) U kraljevstvu carice od Sabe (Zagreb: Naprijed)

Štambuk, Zdenko (1961) Od Zanzibara do Mjesečevih planina (Zagreb: Naprijed)

Štambuk, Zdenko (1961) Zapisi iz Afrike (Zagreb: Naprijed)

\section{Additional Secondary Historical Literature}

Bogetić, Dragan (2000) Jugoslavija i Zapad 1952-1955: Jugoslovensko približavanje NATO-u (Beograd: Službeni list Srbije)

Bogetić, Dragan, Bogetić, Olivera (1981) Nastanak i razvoj pokreta nesvrstanosti (Beograd: Export-press)

Bogetić, Dragan, Dimić, Ljubodrag (2013) Beogradska konferencija nesvrstanih zemalja (Beograd: Zavod)

Čavoški, Jovan (2009) Jugoslavija i kinesko-indijski konflikt 1959-1962 (Beograd:

Institut za noviju istoriju Srbije)

Mates, Leo (1976) Međunarodni odnosi socijalističke Jugoslavije (Beograd: Nolit) Petković, Ranko (1981) Nesvrstanost: Nezavisan, vanblokovski i globalni faktor u medjunarodnim odnosima (Zagreb, Školska knjiga)

Petranović, Branko (1981) Istorija Jugoslavije 1918-1978 (Beograd: Nolit)

Petrović, Vladimir (2010) Titova lična diplomatija: Studije i dokumentarni prilozi

(Beograd: Institut za savremenu istoriju) 


\section{References:}

Abraham, Itty (2008) 'Bandung and State Formation in Post-colonial Asia' in Seng Tan and Amitav Acharya, eds., Bandung Revisited: The Legacy of the 1955 Afro-Asian Conference for International Order, 48-67, Singapore: NUS Press.

Alexander, Jeffrey C. (2006) 'Cultural Pragmatics: Social Performance between Ritual and Strategy' in Jeffrey C. Alexander, Bernhard Giesen and Jason L. Mast, eds., Social Performance: Symbolic Action, Cultural Pragmatics, and Ritual, 29-90, Cambridge: Cambridge University Press.

Anievas, Alexander, Nivi Manchanda and Robbie Shilliam (2015) Race and racism in international relations : confronting the global colour line. London: Routledge.

Baker, Catherine (forthcoming). Race and the Yugoslav Region. Manchester: Manchester University Press.

Baldwin, Kate A. (2002) Beyond the color line and the Iron Curtain : reading encounters between Black and Red, 1922-1963. Durham, N.C.: Duke University Press.

Bartulin, Nevenko. 2014. The Racial Idea in the Independent State of Croatia: Origins and Theory. Leiden: Brill.

Berkok, Ugurhan G and Binyam Solomon (2011) 'Peacekeeping, private benefits and common agency' in Derek L. Braddon and Keith Hartley, eds., Handbook on the Economics of Conflict, 265-292, Cheltenham, UK: Edward Elgar.

Bilandžić, Dušan (1985) Historija Socijalističke Federativne Republike Jugoslavije : glavni procesi 1918-1985. Zagreb: Školska knj.

Bogetić, Dragan (1990) Koreni jugoslovenskog opredeljenja za nesvrstanost. Beograd: Institut za savremenu istoriju.

Bogetić, Dragan (2006) Nova strategija jugoslovenske spoljne politike 1951-1961. Beograd: Institut za savremenu istoriju.

Bondžić, Dragomir (2011) Misao bez pasoša: međunarodna saradnja Beogradskog univerziteta 1945-1960. Beograd: Institut za savremenu istoriju.

Bondžić, Dragomir and Slobodan Selinić (2008) 'Pogled iz Beograda na Bandunšku konferenciju 1955. godine.' Istorija 20. veka 26(1): 71-84.

Bourdieu, Pierre (1993) The field of cultural production : essays on art and literature. New York: Columbia University Press.

Byrne, Jeffrey James (2015) 'Beyond Continents, Colours, and the Cold War: Yugoslavia, Algeria, and the Struggle for Non-Alignment.' The International History Review. 
Čavoški, Jovan (2014) 'Between Great Powers and Third World Neutralists: Yugoslavia and the Belgrade Conference of the Non-Aligned Movement, 1961' in Nataša Mišković, Harald Fischer-Tiné and Nada Boškovska, eds., The Non-Aligned Movement and the Cold War: Delhi - Bandung - Belgrade, 184-206, London: Routledge.

Davis, Alexander E and Vineet Thakur (2016) 'Walking the Thin Line: India's AntiRacist Diplomatic Practice in South Africa, Canada, and Australia, 1946-55.' The International History Review: 1-20.

De Carvalho, Benjamin and Iver B Neumann (2014) 'Introduction: Small states and status' in Benjamin De Carvalho and Iver B Neumann, eds., Small State Status Seeking: Norway's Quest for International Standing, 1-21, London: Routledge.

De Carvalho, Benjamin and Iver B Neumann (2014) Small State Status Seeking: Norway's Quest for International Standing. London: Routledge.

Dinkel, Jurgen (2014) "To Grab the Headlines in the World Press': Non-aligned Summits as Media Events' in Nataša Mišković, Harald Fischer-Tiné and Nada Boškovska, eds., The Non-Aligned Movement and the Cold War: Delhi-Bandung-Belgrade, 207-225, London: Routledge.

Drapac, Vesna (2010) Constructing Yugoslavia: a Transnational History. London: Macmillan.

Duque, Marina (2016) Recognizing International Status: A Relational Approach. International Studies Association Annual Convention, Atlanta, GA.

Foreign Office of Yugoslavia (1954) Burma. Belgrade, Archive of Yugoslavia. KPR I$2 / 4$.

Foreign Office of Yugoslavia (1954) India. Belgrade, Archives of Yugoslavia. KPR I2/4.

Gerits, Frank (2016) 'Bandung as the call for a better development project: US, British, French and Gold Coast perceptions of the Afro-Asian Conference (1955).' Cold War History 16(3): 255-272.

Gupta, Akhil (1992) 'The song of the nonaligned world: transnational identities and the reinscription of space in late capitalism.' Cultural Anthropology 7(1): 63-79.

Hadžić, Fadil (1961) 'Uvod' in Fadil Hadžić and Dragoslav Adamović, eds., Put oko svijeta: putopisi, Zagreb: Novinarsko izdavačko poduzeće.

Hajer, Maarten A. (2009) Authoritative governance: policy-making in the age of mediatization. Oxford: Oxford University Press. 
Hozić, Aida A. (2016) 'False Memories, Real Political Imaginaries: Jovanka Broz in Bandung' in Quỳnh N. Phạm and Robbie Shilliam, eds., Meanings of Bandung:

Postcolonial Orders and Decolonial Visions, 95-100, London: Rowman \& Littlefield.

Hozić, Aida A. (2016) Tito's Journey(s) Through Africa: Race and Nation in International Politics. Millennium Conference "Racialised Realities in World Politics", London.

Irwin, Zachary (2016) 'The Untold Stories of Yugoslavia and Nonalignment' in Gorana Ognjenović and Jasna Jozelić, eds., Revolutionary Totalitarianism, Pragmatic Socialism, 139-166, London: Palgrave.

Imre, Anikó. 2005. 'Whiteness in post-socialist eastern Europe: The time of the Gypsies, the end of race'. In Alfred J López ed. Postcolonial Whiteness: a Critical Reader on Race and Empire, 79-102. Albany, NY: SUNY Press.

Janić, Čedomir and Jovo Simišić (2007) Više od letenja: osam decenija Aeroputa i JATa. Beograd: JAT Airways Media Centar.

Jović, Dejan (2009) Yugoslavia: A State that Withered Away, West Lafayette, IN: Purdue University Press.

Kilibarda, Konstantin (2010) Non-Aligned Geographies in the Balkans: Space, Race and Image in the Construction of new 'European' Foreign Policies. Security Beyond the Discipline: Emerging Dialogues on Global Politics, New Orleans, LA, York University Centre for International and Security Studies.

Kullaa, Rinna (2012) Non-alignment and its origins in Cold War Europe: Yugoslavia, Finland and the Soviet challenge: IB Tauris.

Lake, David A. (2014) 'Authority, Status, and the End of the American Century' in T.V. Paul, Deborah Welch Larson and William C. Wohlforth, eds., Status in World Politics, 246-270, New York: Cambridge University Press.

Law, Ian (2012) Red racisms : racism in communist and post-communist contexts. Basingstoke: Palgrave Macmillan.

Lazić, Milorad (2009) 'Neki problemi stranih studenata na jugoslovenskim univerzitetima šezdesetih godina XX veka, s posebnim osvrtom na afričke studente.' Godišnjak za društvenu istoriju 2: 61-78.

Lebow, Richard Ned (2008) A Cultural Theory of International Relations. Cambridge: Cambridge University Press.

Lee, Christopher J (2010) Making a world after empire: The Bandung moment and its political afterlives. Athens: Ohio University Press. 
Lees, Lorraine M. (1997) Keeping Tito afloat: the United States, Yugoslavia, and the Cold War. University Park, Pa.: Pennsylvania State University Press.

Longinović, Tomislav Z. 2011. Vampire Nation: Violence as Cultural Imaginary. Durham, NC: Duke University Press.

Lüthi, Lorenz (2014) 'The Non-Aligned: Apart From and Still Within the Cold War' in Nada Boškovska, Harald Fischer-Tiné and Nataša Mišković, eds., The Non-Aligned Movement and the Cold War: Delhi - Bandung - Belgrade, 97-113, London: Routledge.

Maoz, Zeev (2011) Networks of nations : the evolution, structure, and impact of International Networks, 1816-2001. Cambridge: Cambridge University Press.

Mates, Leo (1970) Nesvrstanost: teorija i savremena praksa. Beograd: Izdanje Instituta za međunarodnu politiku i privredu.

Mattern, Janice Bially and Ayse Zarakol (2016) 'Hierarchies in World Politics.' International Organization 70(3): 623-654.

Mills, Charles W. (1997) The Racial Contract. Ithaca: Cornell University Press.

Mills, Charles W. (2015) 'Global white ignorance' in Matthias Gross and Lindsey McGoe, eds., The Routledge Handbook of Ignorance Studies, 217-227, London: Routledge.

Milutinovic, Zoran (2008) 'Oh, to Be a European! What Rastko Petrović Learnt in Africa' in Wendy Bracewell and Alex Drace-Francis, eds., Under Eastern Eyes: A Comparative Introduction to East European Travel Writing on Europe, 267-291, Budapest: Central European University Press.

Mišković, Nataša (2014) 'Introduction' in Nataša Miškovic, Harald Fischer-Tiné and Nada Boškovska, eds., The Non-Aligned Movement and the Cold War: Delhi - Bandung Belgrade, 1-18, London: Routledge.

Mišković, Nataša, Harald Fischer-Tiné and Nada Boškovska (2014) The Non-Aligned Movement and the Cold War: Delhi-Bandung-Belgrade. London: Routledge.

Parker, Jason (2011) 'Ideology, Race and Nonalignment in US Cold War Foreign Relations: Or, How the Cold War Racialized Neutralism Without Neutralizing Race' in Bevan Sewell and Scott Lucas, eds., Challenging US Foreign Policy: America and the World in the Long Twentieth Century, 75-98, New York: Palgrave.

Pasha, Mustapha K. (2013) 'The 'Bandung Impulse' and International Relations' in Sanjay Seth, eds., Postcolonial Theory and International Relations, 144-165, Abingdon: Routledge.

Pham, Quynh N. and Robbie Shilliam (2016) 'Reviving Bandung' in Quỳnh N. Pham and Robbie Shilliam, eds., Meanings of Bandung, 1-19, London: Rowman and Littlefield. 
Pouliot, Vincent (2016) International pecking orders : the politics and practice of multilateral diplomacy. New York: Cambridge University Press.

Prashad, Vijay (2008) The darker nations: a people's history of the Third World: The New Press.

Radenković, Đorđe (1961) 'Pustina i ljudi (Iran)' in Fadil Hadžić and Dragoslav Adamović, eds., Put oko svijeta: putopisi, Zagreb: Novinarsko izdavačko poduzeće.

Rajak, Svetozar (2011) Yugoslavia and the Soviet Union in the early Cold War: reconciliation, comradeship, confrontation, 1953-1957. London: Routledge.

Rajak, Svetozar (2014) 'No Bargaining Chips, No Spheres of Interest: The Yugoslav Origins of Cold War Non-Alignment.' Journal of Cold War Studies 16(1): 146-179.

Rajak, Svetozar (2016) '"Companions in Misfortune" : From passive neutralism to active un-commitment - the critical role of Yugoslavia' in Sandra Bott, Jussi M. Hanhimaki, Janick Marina Schaufelbuehl and Marco Wyss, eds., Neutrality and Neutralism in the Global Cold War: Between or Within the Bloc?, 72-89, London: Routledge.

Rakove, Robert B (2014) 'Two roads to Belgrade: the United States, Great Britain, and the first nonaligned conference.' Cold War History 14(3): 337-357.

Ringmar, Erik (2012) 'Performing international systems: two East-Asian alternatives to the Westphalian order.' International Organization 66(01): 1-25.

Ringmar, Erik (2016) 'How the world stage makes its subjects: an embodied critique of constructivist IR theory.' Journal of International Relations and Development 19(1): 101125 .

Rubinstein, Alvin Z. (1970) Yugoslavia and the nonaligned world. Princeton, N.J.,: Princeton University Press.

Rus, Vojan (1964) 'Pogled na socijalističku orijentaciju zemalja u razvoju.' Komunist: organ Centralnog komiteta Saveza komunista Jugoslavije July-August.

Sardelić, Julija (2014) 'Antiziganism as cultural racism: before and after the disintegration of Yugoslavia.' In Timofey Agarin, ed, When Stereotype Meets Prejudice: Antiziganism in European Societies, 205-27. Stuttgart: Ibidem Verlag.

Savez socijalističke omladine Jugoslavije (1958) Strani studenti u FNRJ. Beograd, Arhiv Jugoslavije. 114.

Shimazu, Naoko (2014) 'Diplomacy as theatre: staging the Bandung Conference of 1955.' Modern Asian Studies 48(01): 225-252.

Sladojević, Ana (2015) Slike o Africi/Images of Africa. Belgrade: Museum of Contemporary Art. 
Spaskovska, Ljubica (2015) 'From the European periphery to the global arena and back transformations of global citizenship in the former Yugoslavia,' Paper presented at the ASN World Convention, Columbia University, 23-25 April.

Sretenović, Dejan (2004) Crno telo, bele maske. Beograd: Muzej afričke umetnosti.

Šmitek, Zmago, Aleksandra-Sanja Lazarević and Đurđica Petrović (1993) 'Notes sur les voyageurs et explorateurs slovènes, croates et serbes en Afrique avant 1918 et sur leurs collections'. Revue française d'histoire d'outre-mer 80 (300): 389-408.

Tadić, Bojana (1976) Nesvrstanost u teoriji i praksi međunarodnih odnosa. Beograd: Institut za međunarodnu politiku i privredu.

Tito, Josip Broz (1955) Speech in Karlovac. Belgrade, Archive of Yugoslavia. KPR I$2 / 4$.

Tito, Josip Broz (1959) Govori i članci. Zagreb: Naprijed.

Tito, Josip Broz (1959) Speech in Titov Veles. Belgrade, Archives of Yugoslavia. KPR $1-2 / 11$.

Tito, Josip Broz (1963) Selected speeches and articles, 1941-1961. Zagreb: Naprijed.

Tito, Josip Broz (1977) Jugoslavija u borbi za nezavisnost i nesvrstanost. Sarajevo: Svjetlost.

Tito, Josip Broz (1982) Nezavisnost i savremeni svijet. Beograd: Izdavački centar Komunist.

Tito, Josip Broz and Edvard Kardelj (1977) Nesvrstanost, izraz interesa cijelog čovječanstva. Sarajevo: Oslobođenje.

Vieira, Marco A (2016) 'Understanding Resilience in International Relations: The NonAligned Movement and Ontological Security.' International Studies Review: viw002.

Vitalis, Robert (2013) 'The Midnight Ride of Kwame Nkrumah and Other Fables of Bandung (Ban-doong).' Humanity: An International Journal of Human Rights, Humanitarianism, and Development 4(2): 261-288.

Volgy, Thomas J., Jennifer L. Miller, Jacob Cramer, Megan Hauser and Paul Bezerra (2014) An Exploration Into Status Attribution in International Politics. Occasional Paper Series on Political Science and Public Policy Research. Tucson, School of Government and Public Policy, University of Arizona.

Vucetic, Srdjan (2015) "Against Race Taboos: The Global Colour Line in Philosophical Discourse." In Alexander Anievas, Nivi Manchanda and Robbie Shilliam, eds., Race and Racism in International Relations: Confronting the Global Colour Line, 98-114, Abingdon: Routledge. 
Vucetic, Srdjan (2017). Global IR and Global White Ignorance, in: TRAFO - Blog for Transregional Research, 01.06.2017, https://trafo.hypotheses.org/6677

Vuletic, Dean (2010) 'European Sounds, Yugoslav Visions: Performing Yugoslavia at the Eurovision Song Contest' in Breda Luthar and Maruša Pušnik, eds., Remembering Utopia: The Culture of Everyday Life in Yugoslavia, 121-144, Washington, DC: New Academia.

Willetts, Peter (1978) The non-aligned movement: the origins of a Third World alliance. London: Pinter Pub Ltd.

\section{Notes}

${ }^{\mathrm{i}}$ Coined by Bandung delegates and known as bandunški duh to contemporary Yugoslav officials, the phrase had multiple meanings from the beginning, not all which foregrounded or even implied decolonial or anti-racist politics. Bondžić and Selinić 2008: 77; also see, inter alia, Lee 2010, Parker 2011, Pasha 2013, Vitalis 2013, Mišković, Fischer-Tiné et al. 2014, Pham and Shilliam 2016.

ii The fact that it has outlived the Cold War would have humored its putative founders. With 120 members, the NAM is today second in size only to the G-77, a grouping of nations that also emerged in the 1960s in the context of Third World-ism, but which focuses on issues of global economic governance. Its last summit, held on 17-18 September 2016 in Venezuela, was an almost farcical affair attended by 35 heads of state, prompting many observers to once again dismiss the movement as a relic of a bygone era. An entity that never cared to develop a charter, secretariat or even a website, the NAM has always been more akin to a transnational or global identity rather than to an international organisation. See Willetts 1978, Gupta 1992. This is important to keep in mind when evaluating its relevance, resilience, effectiveness, coherence, and legitimacy. Compare Vieira 2016 and Lüthi 2014.

iii This particular myth is reflected in, and reinforced by, the misuse of historical photographs. Countless authors mistakenly attach the caption "Bandung, 1955" to the photographs of Tito, Nehru and Nasser from their 1956 meeting on the Yugoslav island of Brioni or those of Tito, Nehru, Nasser, Nkrumah and Indonesia's Ahmed Sukarno, the Bandung Conference's host, from their 1960 UN meeting in New York. Vitalis 2013: 266. Also see Hozić 2016.

iv The phrase "darker nations" comes from Prashad 2008.

${ }^{v}$ And in some accounts, they are wrongly presented some sort of anti-racial supremacist non-alignment. Vitalis 2013: 266.

${ }^{\text {vi }}$ For example, Japan, formally an empire, was represented at Bandung, as were the leaders of several newly independent states experimenting with "modern" minority population management projects. On the latter, see Abraham 2008. 
${ }^{\text {vii }}$ Latest historical research on Bandung is now showcased on the blog "Afro-Asian Visions: New Perspectives on Decolonisation and the Cold War" at https://medium.com/afro-asian-visions.

viii The other key institution was the League of Communists of Yugoslavia Commission for International Relations. Kullaa 2012: 16-7, also see Bogetić 1990: 212.

ix By this time, Stalin's death had prompted Khruschev and Tito to "normalise" relations between their two countries in 1954; in 1958 Yugoslavia stopped receiving US military aid. Yugoslavia also considered and pursued other policy options for overcoming its post1948 isolation. In 1953, for example, it signed a military alliance with Greece and Turkey, while also considering the pros and cons of adopting the policy of neutrality Finland-style (Kullaa 2012: Ch. 4; Bogetić 1990, Bogetić 2006; Lees 1997). ${ }^{x}$ Compare Rajak 2011 and Kullaa 2012, for example. Nehru's endorsement of nonalignment was ambiguous in those years. At Bandung, he spoke in favor of neutralism, but later re-endorsed nonalignment, notably during his visits to Yugoslavia in the summers of 1955 and 1958.

${ }^{\mathrm{xi}}$ For key primary and secondary sources consulted, see Appendix. On race, including the prevailing mid-twentieth understandings of race and racialised hierarchies, see Vucetic 2015. Yugoslav whiteness in the context of the NAM remains unexamined save for the path-breaking work by Kilibarda 2010.

xii Appendix. The goal was to account for both explicit and implicit ideologies, discourses, institutions and practices circulating in Tito's Yugoslavia in the 1950s and 1960s. See Mills 2015: 218, and Vucetic 2017.

xiii We treated texts left behind by seasoned Party intellectuals like Kardelj, Pijade and Đilas as the most likely case for the ruling elite's race consciousness and articulations of anti-racist politics. A source that comes closest to a sustained critique of racism we identified is the 1962 book Crno na belo (Black on White) by surrealist poet Oskar Davičo (Appendix).

${ }^{\text {xiv }}$ We do not deny that postwar Yugoslavia practiced internal colonialism and sought to exert authority abroad. Albania's socialist government, for one, regarded Yugoslavia as an imperial power, the NAM policy being a case in point (Irwin 2016: 144).

${ }^{\mathrm{xv}}$ Students from Arab countries reported much better treatment if they studied in Sarajevo, where the Muslim community was more friendly and open to their cultural needs (Lazić 2009). On the influence of NAM students on Yugoslav popular culture, see Baker forthcoming, Ch.1.

${ }^{x v i}$ The government and citizens of Titoist Yugoslavia followed other contemporary European trends in practicing racial politics. Like virtually all other Eastern European governments after 1945, Tito's regime expelled tens of thousands of Yugoslavia's ethnic German and Italian population on the basis of racialised understandings of loyalty and guilt. Similarly, the Titoist discourse, institutions and practice of "brotherhood and unity," while maintaining a degree of harmony and ethnic accommodation between and among the "constituent nations" (Croats, Serbs, etc.) and most "nationalities" (Ukrainians, Slovaks, etc.) never quite hampered open racism towards the Roma or the Albanians. Practically throughout the twentieth century, Yugoslavs routinely cast their fellow citizens of Albanian ethnicity as a "lower race" (Jović, 2009: 287, fn. 15, also see 
Longinović, 2011; Sardelić, 2014, Bartulin 2014, Baker forthcoming; for racism in postwar socialist Eastern Europe, see Baldwin 2002, Imre 2005 and Law 2012). The larger point is that forms of racism-intersecting with gender, ethnicity, class, sexuality, post-coloniality and other axes of human differences-can be localised in every part of the modern world (Vucetic 2015).

xvii Yugoslavia's Marxist academics made similar points. "Underdeveloped socialism," argued one, was subject to "severe contradictions," such as those arising from residues of clientelism and authoritarianism (Rus 1964).

xviii That status is always conditioned by peer groups is also a point made by economists or economics-inspired IR scholars who see status as a club good. See, inter alia, Berkok and Solomon 2011 and Lake 2014.

xix "Small state" is convenient shorthand for all states that cannot match the various criteria of great powerhood, whether the objectivist guns-and-butter counts, intersubjectivist understandings of role and responsibility, or some combination of both. Most IR and historical literatures classify Titoist Yugoslavia as a "middle" or "medium power". Yet, Yugoslavia's leading thinkers of the time quite explicitly invoked smallness. At the London meeting of the UN General Assembly in 1945, Kardelj forcefully argued against the notion that small states "have no role, that their positions are dependent only on the solutions of great powers (velike države)," (Borba, 20 January 1946), as did Tito, in many of his speeches: "Small nations can play an enormous role in preventing a new world war if they fight together for equal relationships between big and small" (Tito 1959: 239-40).

${ }^{\mathrm{xx}}$ Following Bourdieu's field theory, status-seeking in any field involves a struggle over the definition and distribution of capital. If dominant actors employ conservation strategies to maintain status, those who hold subordinate position can chose between either attempting to succeed or at least support dominant actors or subverting the legitimacy of the status quo (Bourdieu 1993: 82-84). Compare with De Carvalho and Neumann 2014: 10-1.

${ }^{\mathrm{xxi}}$ Note, however, performance is related to, but not the same as, performativity"stylised repetition of acts," in Judith Butler's formulation. Inspired by John Austin, Guy Debord, Murray Edelman, Jacques Derrida, Jean Baudrillard, Bruno Latour and other thinkers, the latter evokes a different (and arguably more established) body of work in IR (Ringmar, 2012: 3, n. 9; Ibid., 2016: 105-6).

xxii Note that Ringmar goes much deeper to theorise performances from the perspective of the human body and embodied interactions that are at once physiological-neurological and social (Ringmar 2016: 102, 108). Citing the work of Vittorio Gallese, he also draws attention to the hypothesised link between such embodied interactions on the one hand and political solidarity on the other (Ibid.: 110, cf. 119, fn. 3).

xxiii Some of this is captured in the 1961-1962-vintage 10-minute Filmske novosti newsreel "Historical conference in Belgrade" (in English), available on YouTube: https://www.youtube.com/watch?v=vfsjKTj4Qpw. Like in Bandung, citizens were instructed to be on their best behaviour towards visitors, and local high school and university foreign language students were mobilised to provide city tours (Dinkel 2014: 209-10).

${ }^{\text {xxiv }}$ We draw heavily from Dinkel 2014 for the following paragraphs. 
${ }^{\mathrm{xxv}}$ Compared to Brioni, where the stage was a single joint press conference covered by two dozen journalists, Belgrade offered a media spectacle akin to a major international sporting event. In addition to hundreds of foreign conference officials and probably around a thousand of locals ones, the hosts invited over 1,000 journalists from over 50 countries, putting them up in student residences of the University of Belgrade while also providing them with ample working space and technical equipment. Translators from the participating countries - the conference was to be simultaneously translated into Arabic, English, French, and Spanish-received similar help.

${ }^{x x v i}$ Tito, for one, was not among NAM leaders who had known each other since the 1927 Conference Against Imperialism in Brussels. In fact, it is likely that none of the Yugoslav communists who came to lead postwar Yugoslavia had any experience with any of the interwar transnational advocacy networks that connected and mobilised anti-imperialist intellectuals calling for international (racial) equality. For context, see Mišković 2014, esp. 2-3; Drapac 2010; Prashad 2008.

xxvii Hajer's notion of "discourse coalitions" - incoherent assemblages of meanings that nevertheless are strategic and potentially highly politically consequential-is helpful here (Hajer 2009: 64). 